\title{
MicroRNA-96 Promotes Tumor Invasion in Colorectal Cancer via RECK
}

\author{
YASUHITO ISEKI, MASATSUNE SHIBUTANI, KIYOSHI MAEDA, HISASHI NAGAHARA, \\ TATSUNARI FUKUOKA, SHINJI MATSUTANI, KOSEI HIRAKAWA and MASAICHI OHIRA \\ Department of Surgical Oncology, Osaka City University Graduate School of Medicine, Osaka, Japan
}

\begin{abstract}
Background: miR-96 is reported to inhibit reversion cysteine-rich Kazal motif (RECK), which is associated with tumor invasion, in solid cancer types (e.g. breast cancer, non-small cell lung cancer, esophageal cancer). The purpose of this study is to clarify whether miR-96 is similarly associated with tumor invasion in colorectal cancer. Materials and Methods: We performed western blotting to investigate the expression of RECK when miR-96 mimics or inhibitors were transferred into HCT-116 colorectal cancer cells. The RECK mRNA level was assessed by a reverse transcription polymerase chain reaction. An invasion assay was used to evaluate tumor invasion. Results: The expression of RECK was inhibited by the transfection of miR-96 mimics. RECK mRNA level was reduced by miR-96 mimics and increased by miR-96 inhibitor. In the invasion assay, miR-96 mimics were shown to promote tumor invasion. Conclusion: miR-96 may be associated with tumor invasion through inhibition of RECK expression in colorectal cancer.
\end{abstract}

Colorectal cancer (CRC) is the third most common form of cancer worldwide (1). Chemotherapy and operative techniques for CRC have improved; however, one-third of patients with CRC who receive surgical treatment die within 5 years of surgery; thus, the prognosis of CRC remains poor $(2,3)$. The prognosis of metastatic colorectal cancer is worse. Thus, elucidating the mechanisms of metastasis and tumor invasion is important for improving the prognosis of this disease (4).

MicroRNAs (miRs), which are small non-coding RNAs, unite with the 3 '-untranslated region on mRNA to regulate the expression of proteins via degradation of mRNA or by

Correspondence to: Masatsune Shibutani, MD, Ph.D. Osaka City University Graduate School of Medicine, Department of Surgical Oncology, 1-4-3 Asahi-machi Abeno-Ku Osaka City, Osaka Prefecture, 545-8585, Japan. Tel: +81 666453838, Fax: +81 666466450, e-mail: fbxbj429@ybb.ne.jp

Key Words: MicroRNA, RECK, MiR-96, cell invasion, colorectal cancer. inhibiting the translation of proteins (5). The expression of miR in tumors is different from that in normal tissue; the miR level in carcinoma is reported to be associated with tumor invasion, proliferation, metastasis and resistance to anticancer agents (6-9). However, there are many unanswered questions regarding the effect of changes in the levels of miRs in cancer tissue.

More than 3,000 miRs have been reported. In particular, miR-96 is up-regulated more highly in breast (10), non-small cell lung (11), esophageal (12), hepatocellular (13), endometrial (14) and colorectal cancer (15). The up-regulation of miR-96 is associated with a poor prognosis in CRC (15); thus, miR-96 is referred to as an 'onco-miR' in CRC $(15,16)$.

miR-96 activates matrix metalloproteinases (MMP), which regulate the remodeling of the extra cellular matrix (ECM) via the expression of reversion cysteine-rich Kazal motif (RECK), to induce cell invasion in breast (10), non-small cell lung (11), and esophageal (12) cancer. However, the functions of miRs differ in each of these cancer types and it is unclear whether miR-96 is associated with tumor invasion in CRC via RECK.

The aim of this study was to clarify whether $m i R-96$ regulates tumor invasion in CRC via RECK.

\section{Materials and Methods}

Cell line. A colon cancer cell line, HCT-116, was used. HCT-116 was obtained from the American Type Culture Collection (Rockville, MD, USA) and were incubated in Dulbecco's modified Eagle's medium (DMEM; Wako, Osaka, Japan) containing 10\% fetal bovine serum (FBS; Nichirei, Tokyo, Japan), $100 \mathrm{IU} / \mathrm{ml}$ penicillin (Wako), $100 \mathrm{mg} / \mathrm{ml}$ streptomycin (Wako) and $0.5 \mathrm{mM}$ sodium pyruvate (Wako) at $37^{\circ} \mathrm{C}$ with $5 \% \mathrm{CO}_{2}$.

Transfection of miR mimic and inhibitor. HCT-116 cells were transfected with mirVana ${ }^{\circledR}$ miRNA mimic (MC12537), mirVana miRNA inhibitor (MH12537), mirVana ${ }^{\circledR}$ miRNA Inhibitor negative control (NC) (4464076) or mirVana miRNA Mimic NC (4464058) according to the manufacturer's instructions (Applied Biosystems). A total of $1 \times 10^{6}$ cells were then incubated in lysis medium containing $9 \mu \mathrm{l}$ of lipofectamine RNAiMAX ${ }^{\circledR}$ (Life Technologies, Carlsbad, CA, USA), $150 \mu \mathrm{l}$ of OptiMEM ${ }^{\circledR}$ (Life Technologies), 


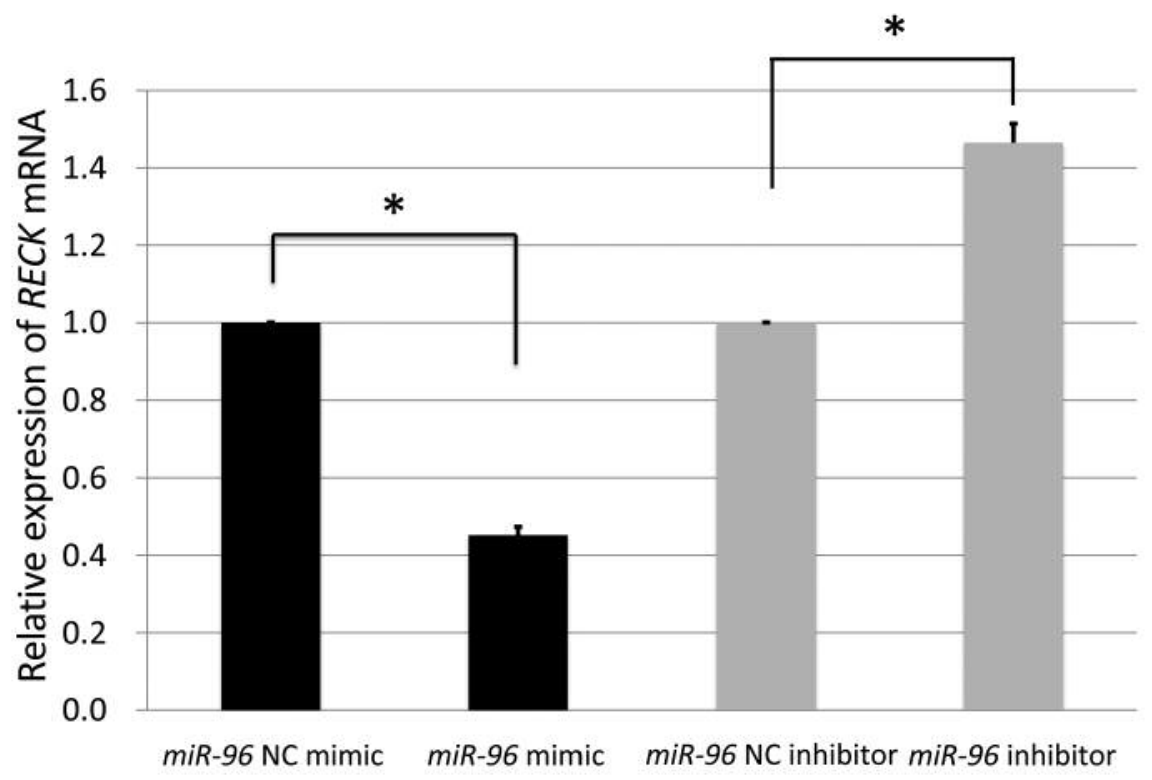

Figure 1. Quantitative real time-polymerase chain reaction for mRNA expression reversion cysteine-rich Kazal motif (RECK) of HCT-116 cells transfected with miR-96 mimic, miR-96 inhibitor, miR-96 negative control (NC) mimic or miR-96-NC inhibitor is shown. miR-96 mimic significantly reduced the RECK mRNA level compared with miR-96-NC mimic * $(p<0.05)$. miR-96 inhibitor increased the RECK mRNA level significantly compared with miR-NC inhibitor.

and $30 \mathrm{pmol} \mathrm{miR}$ mimic or $30 \mathrm{pmol} \mathrm{miR}$ inhibitor, in a 6-well dish for $5 \mathrm{~min}$ in room air. Then $1.7 \mathrm{ml}$ of DMEM containing $2 \% \mathrm{FBS}$ was added and the cells were incubated for $48 \mathrm{~h}$.

Quantitative reverse transcription-polymerase chain reaction ( $q R T$ $P C R)$. Total RNA was extracted from transfected and parentaI HCT116 cells using an miReasy Mini kit (Life Technologies, Carlsbad, CA, USA), and RNA was transcribed for cDNA using ReverTra Ace ${ }^{\circledR}$ qPCR RT Master Mix (Toyobo, Osaka, Japan), according to the manufacturer's instructions.

We verified the quantification of total RNA using a NanoDrop ND-1000 spectrometer (NanoDrop, Wilmington, DE, USA), and the optical density (OD) ratio at $260 / 280 \mathrm{~nm}$ was utilized for quality control and to determine the concentration of total RNA. A Step One Plus Real-Time PCR System (Applied Biosystems, Foster City, CA, USA) was used for reverse transcription with a TaqMan ${ }^{\circledR}$ Gene Expression Assay (Thermo Fisher Scientific, Waltham, MA, USA) for RECK (Hs01019185; Applied Biosystems) and glyceraldehyde3-phosphate dehydrogenase (GAPDH) (Hs02758911; Applied Biosystems). GAPDH was used as an endogenous control. The cycle threshold $(\mathrm{Ct})$ values were used to calculate the relative expression ratios between the control and treated cells. The PCR cycle conditions were follows: $30 \mathrm{~s}$ at $95^{\circ} \mathrm{C}$, followed by 40 cycles at $10 \mathrm{~s}$ at $95^{\circ} \mathrm{C}, 60 \mathrm{~s}$ at $60^{\circ} \mathrm{C}$ and $30 \mathrm{~s}$ at $70^{\circ} \mathrm{C}$. The relative quantification of the gene expression was performed using the $2^{-\Delta \Delta \mathrm{Ct}}$ method. Each sample was examined in triplicate.

Western blotting. The protein expression was analyzed by western blotting. The transfected cells were washed with phosphate-buffered saline (PBS) (Wako), then centrifuged for $20 \mathrm{~s}$ at $13,000 \times g$. The cells were dissolved by $400 \mu \mathrm{l}$ PRO-PREPTM (iNtRON,

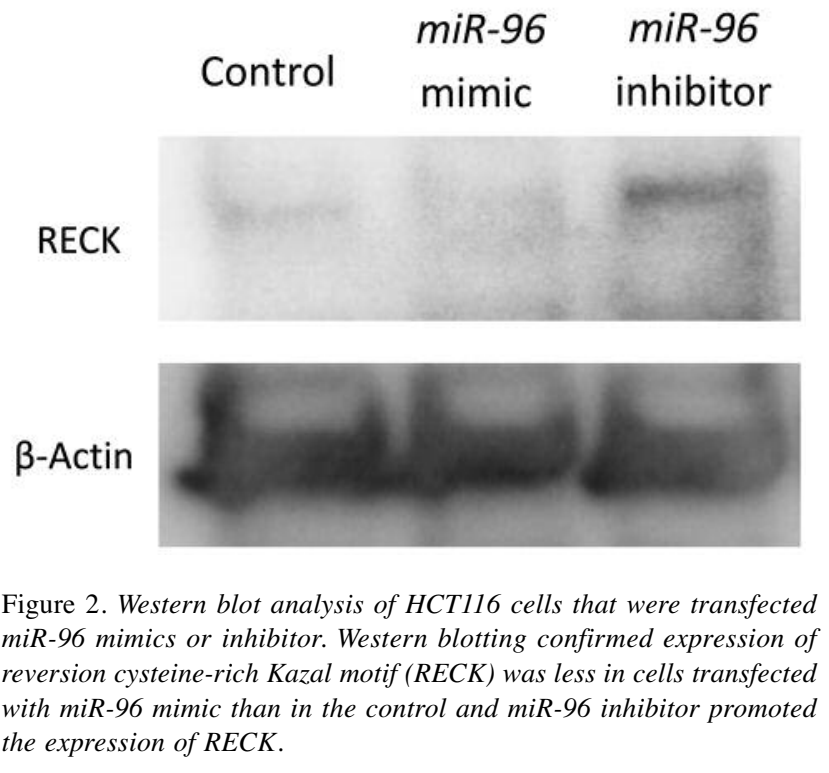

Seongnam-shi, Korea) according to the manufacturer's instructions. The lysis solution was centrifuged at $4^{\circ} \mathrm{C}$ for $5 \mathrm{~min}$ at $13000 \times \mathrm{g}$ and the supernatant was retrieved. We then determined the concentration of protein using an ND-1000 spectrometer ${ }^{\mathrm{TM}}$ (NanoDrop). We adjusted the protein level of each sample, and performed electrophoresis using NuPAGE ${ }^{\circledR}$ Tris-Acetate SDS 

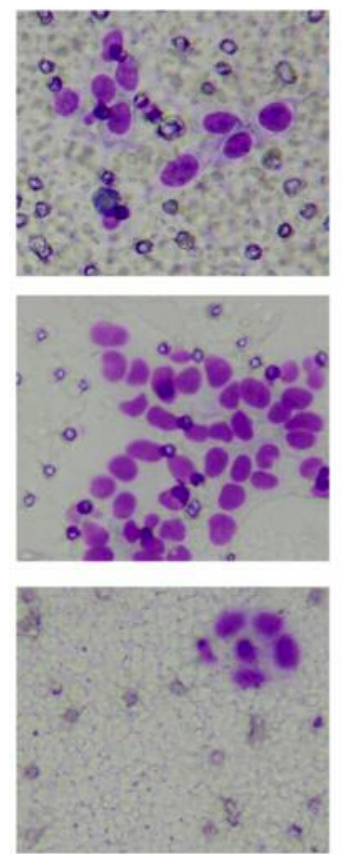

Negative control mimic

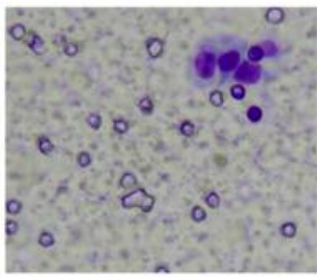

\section{miR-96 inhibitor}

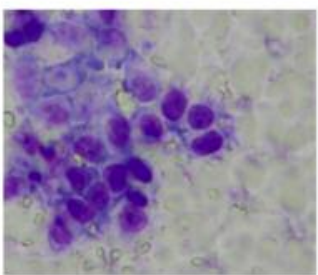

\section{Negative control inhibitor}

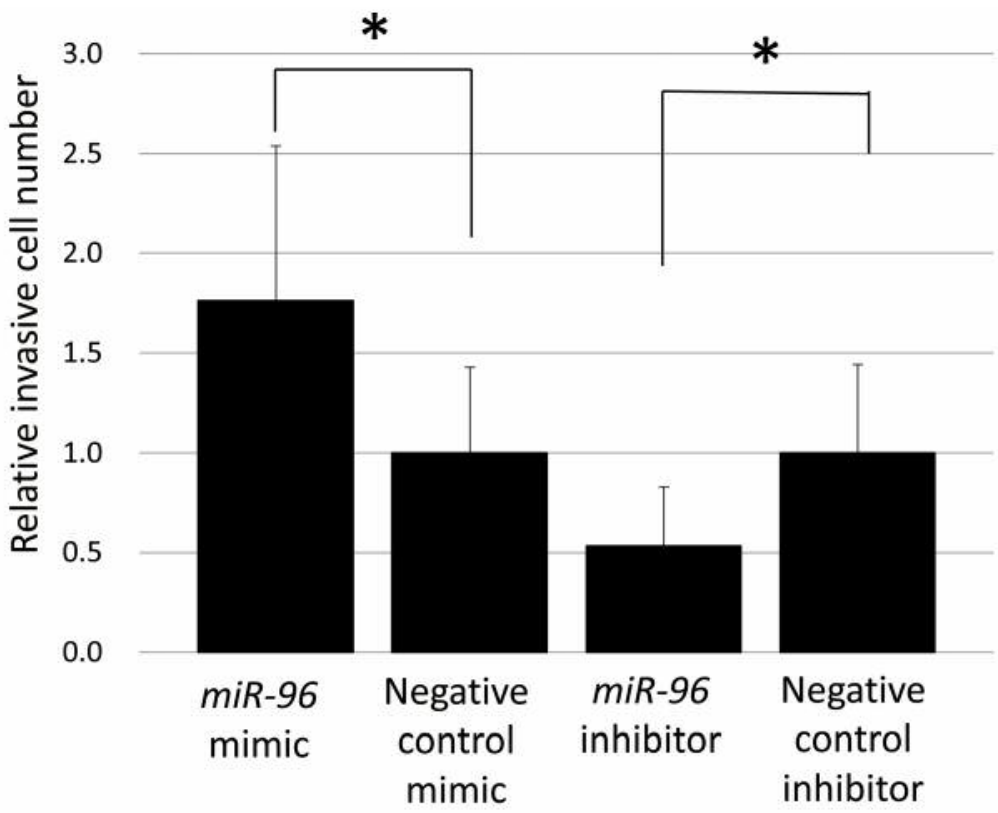

Figure 3. Invasion assay of HCT116 cells that were transfected miR mimics or inhibitor. miR-96 mimic significantly increased the invasion of tumor cells in comparison to negative control $(N C)$-mimic $\left({ }^{*} p<0.05\right)$. miR-96 inhibitor reduced the invasion of tumor cells in comparison to NC-inhibitor.

sodium pyruvate (Wako). After $48 \mathrm{~h}$ incubation, we removed the cells on the upper membrane, and counted the number of cells in five random fields $(\times 200)$ on each membrane. The cells were incubated for $48 \mathrm{~h}$. The mean number of cells was calculated after the lower membranes were fixed and stained using Diff-Quik (Sysmex, Kobe, Japan), according to manufacturer's instructions.

Statistical analysis. JMP 11 software (SAS Institute, Cary, NC, USA) was used to analyze the data. Differences between groups were analyzed using the Mann-Whitney test and Student's $t$-test. $p$-Values of less than 0.05 were considered to indicate statistical significance.

\section{Results}

miR-96 reduced RECK $m R N A$ and inhibited the expression of $R E C K$. The RT-PCR revealed that $m i R-96$ mimic significantly reduced the mRNA level of RECK in comparison to NC 


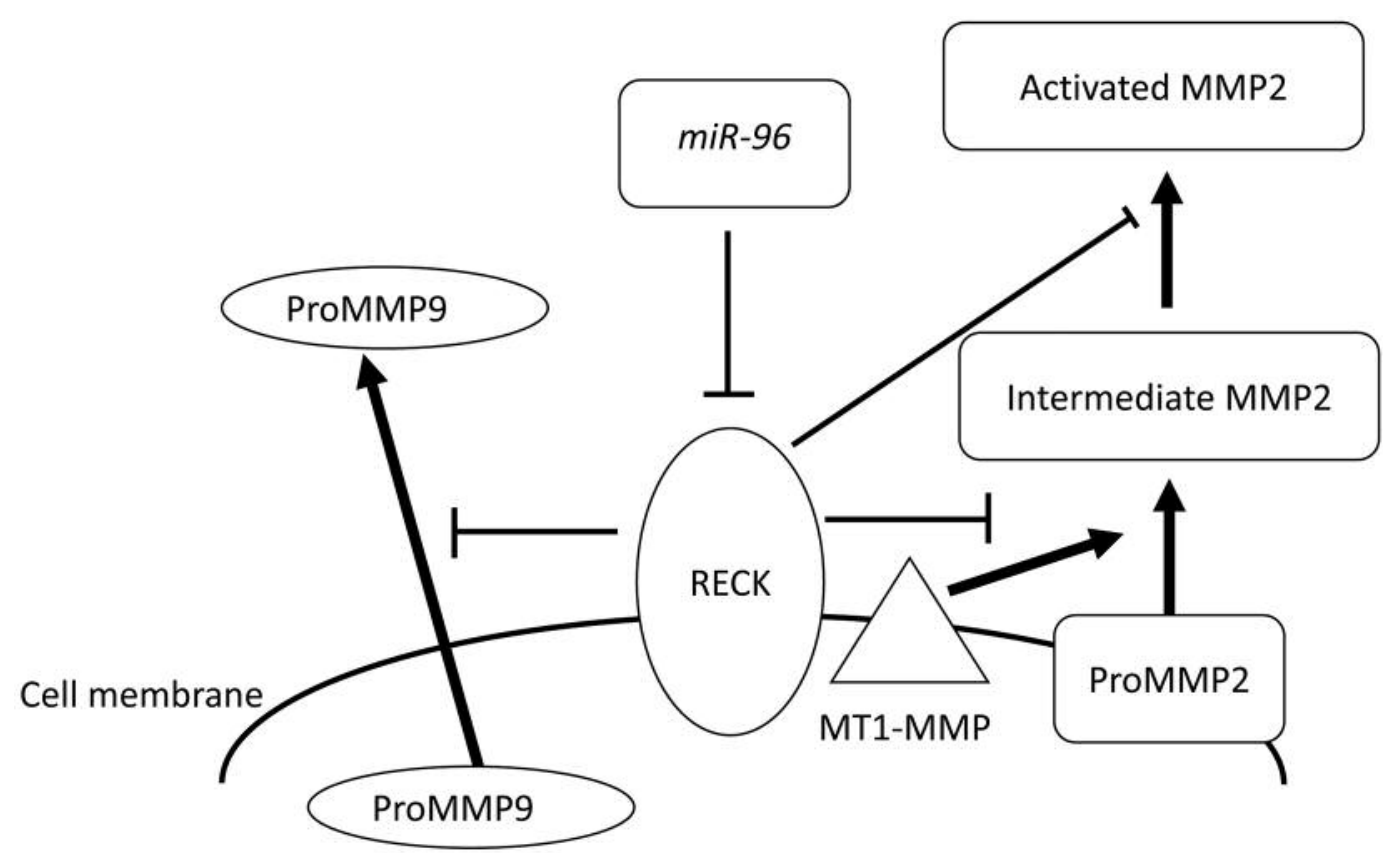

Figure 4. The mechanisms of miR-96, reversion cysteine-rich Kazal motif (RECK) and matrix metalloproteinases (MMP) action in colorectal cancer (CRC) cells. miR-96 may be associated with tumor invasion through inhibition of the RECK expression in CRC cells. RECK inhibits the change from proMMP2 to intermediate MMP2 and from intermediate MMP2 to activated MMP2. miR-96 also reduces proMMP9 secretion, reducing the $M M P$ levels, leading to a decrease in the degradation of the extracellular matrix(ECM) and thereby inhibiting tumor cell invasion. MT1-MMP: membrane type 1- matrix metalloproteinase.

mimic. In contrast, miR-96 inhibitor increased the RECK mRNA level in comparison to NC inhibitor (Figure 1).

Western blotting confirmed that miR-96 mimic reduced the expression of RECK to less than that of the control and miR-96 inhibitor increased RECK expression in comparison to the control (Figure 2).

miR-96 up-regulated tumor cell invasion. miR-96 mimic increased tumor cell invasion in comparison to $\mathrm{NC}$ mimic, while miR-96 inhibitor reduced tumor cell invasion in comparison to NC inhibitor (Figure 3).

\section{Discussion}

The present study revealed that $m i R-96$ mimic increased tumor cell invasion by inhibiting the expression of RECK in the HCT-116 CRC cell line.

RECK is a $110 \mathrm{kDa}$ glycoprotein of the cell membrane anchor type. miR-96 has been reported to inhibit RECK expression in different types of cancer (10-12). The remodeling of the ECM is important for the invasion of cancer cells and RECK controls MMPs that are involved in the remodeling of the ECM $(17,18)$. MMP2, MMP9 and membrane type 1 (MT1)-MMP induce a decrease in adhesion between the ECM and cells, which leads to tumor cell invasion $(17,18)$. RECK inhibits the change of proMMP2 to intermediate MMP2 and from intermediate MMP2 to activated MMP2, and reduces proMMP9 secretion. In this way RECK reduces MMP levels leading to a decrease in the degradation of the ECM, thereby inhibiting tumor cell invasion (Figure 4) $(17,18)$. RECK can be considered to be a tumor-suppressor gene. In previous reports, the prognosis of patients with CRC with reduced expression of RECK was significantly poor $(17,18)$.

It is reported that $m i R-96$ is also associated with the inhibition of expression of forkhead box protein $\mathrm{O} 1$ and $3 \mathrm{a}$, which are transcription activity factors associated with survival and tumor growth $(19,20)$.

In the future, drugs targeting miR-96 may be applied in the treatment of CRC. However, the factors associated with the progression of cancer, including RECK, are controlled by more than one miR. mir-2l (21) and miR-221 (22) also control the expression of RECK. The further elucidation of the mechanisms underlying the effects of miRs will be necessary before treatments targeting miRs can be used clinically.

\section{Conclusion}

miR-96 may be associated with tumor invasion through inhibition of RECK expression in CRC cells. 


\section{Conflicts of Interest}

The Authors declare that they have no competing interests in regard to this study.

\section{Acknowledgements}

The Authors thank Brian Quinn who provided medical writing services on behalf of JMC, Ltd. and the staff of the Central Laboratory of Osaka City University Medical School for their technical support.

\section{References}

1 Ferlay J, Soerjomataram I, Ervik M, Dikshit R, Eser S, Mathers C, Rebelo M, Parkin DM, Forman D and Bray F: GLOBOCAN 2012 v1.0, Cancer Incidence and Mortality Worldwide: IARC CancerBase No. 11 [Internet]. Lyon, France: International Agency for Research on Cancer; 2013. Available from: http://globocan.iarc.fr, accessed on 6/8/2014.

2 Mcardle CS and Hole DJ: Outcome following surgery for colorectal cancer: analysis by hospital after adjustment for casemix and deprivation. Br J Cancer 86(3): 331-335, 2002.

3 Heinemann V, von Weikersthal LF, Decker T, Kiani A, VehlingKaiser U, Al-Batran SE, Heintges T, Lerchenmüller C, Kahl C, Seipelt G, Kullmann F, Stauch M, Scheithauer W, Hielscher J, Scholz M, Müller S, Link H, Niederle N, Rost A, Höffkes HG, Moehler M, Lindig RU, Modest DP, Rossius L, Kirchner T, Jung A and Stintzing S: FOLFIRI plus cetuximab versus FOLFIRI plus bevacizumab as first-line treatment for patients with metastatic colorectal cancer (FIRE-3): a randomised, open-label, phase 3 trial. Lancet Oncol 15(10): 1065-1075, 2014.

4 Loupakis F, Cremolini C, Masi G, Lonardi S, Zagonel V, Salvatore L, Cortesi E, Tomasello G, Ronzoni M, Spadi R, Zaniboni A, Tonini G, Buonadonna A, Amoroso D, Chiara S, Carlomagno C, Boni C, Allegrini G, Boni L and Falcone A: Initial therapy with FOLFOXIRI and bevacizumab for metastatic colorectal cancer. N Engl J Med 371(17): 1609-1618, 2014.

5 Filipowicz W, Bhattacharyya SN and Sonenberg N: Mechanisms of post-transcriptional regulation by microRNAs: Are the answers in sight? Nat Rev Genetics 9(2): 102-114, 2008.

6 Kim SA, Kim I, Yoon SK, Lee EK and Kuh HJ: Indirect modulation of sensitivity to 5-fluorouracil by microRNA-96 in human colorectal cancer cells. Arch Pharm Res 38(2): 239-248, 2015.

7 Asangani IA, Rasheed SA, Nikolova DA, Leupold JH, Colburn $\mathrm{NH}$, Post S and Allgayer H: MicroRNA-21 (miR-21) posttranscriptionally downregulates tumor suppressor Pdcd4 and stimulates invasion, intravasation and metastasis in colorectal cancer. Oncogene 27(15): 2128-2136, 2008.

8 Bartel DP: MicroRNAs: genomics, biogenesis, mechanism, and function. Cell 116(2): 281-297, 2004.

9 Iseki Y, Shibutani M, Maeda K, Nagahara H, Fukuoka T, Ikeya T, Matsutani S, Kimura K, Toyokawa T, Amano R, Tanaka H, Muguruma K, Hirakawa K and Ohira M: Prognostic significance of microRNA-21 expression in patients with unresectable metastatic colon cancer. Anticancer Res 36(10): 5145-5151, 2016.

10 Zhang J, Kong X, Li J, Luo Q, Li X, Shen L, Chen L and Fang L: miR-96 promotes tumor proliferation and invasion by targeting RECK in breast cancer. Oncol Rep 31(3): 1357-1363, 2014.

11 Guo H, Li Q, Li W, Zheng T, Zhao S and Liu Z: miR-96 downregulates RECK to promote growth and motility of nonsmall cell lung cancer cells. Mol Cell Biochem 390(1-2): 155$160,2014$.

$12 \mathrm{Xia} \mathrm{H}$, Chen S, Chen K, Huang $\mathrm{H}$ and Ma H: miR-96 promotes proliferation and chemo- or radioresistance by down-regulating RECK in esophageal cancer. Biomed Pharmacother 68(8): 951958, 2014.

13 Xu D, He X, Chang Y, Xu C, Jiang X, Sun S and Lin J: Inhibition of $m i R-96$ expression reduces cell proliferation and clonogenicity of HepG2 hepatoma cells. Oncol Rep 29(2): 653-661, 2013.

14 Myatt SS, Wang J, Monteiro LJ, Christian M, Ho KK, Fusi L, Dina RE, Brosens JJ, Ghaem-Maghami $S$ and Lam EW: Definition of microRNAs that repress expression of the tumor suppressor gene FOXO1 in endometrial cancer. Cancer Res 70(1): 367-377, 2010.

15 Ress AL, Stiegelbauer V, Winter E, Schwarzenbacher D, Kiesslich T, Lax S, Jahn S, Deutsch A, Bauernhofer T, Ling H, Samonigg $\mathrm{H}$, Gerger A, Hoefler G and Pichler M: miR-96-5p influences cellular growth and is associated with poor survival in colorectal cancer patients. Mol Carcinog 54(11): 1442-1450, 2015.

16 Gao F and Wang W: MicroRNA-96 promotes the proliferation of colorectal cancer cells and targets tumor protein p53 inducible nuclear protein 1, forkhead box protein O1 (FOXO1) and FOXO3a. Mol Med Rep 11(2): 1200-1206, 2015.

17 van der Jagt MF, Sweep FC, Waas ET, Hendriks T, Ruers TJ, Merry AH, Wobbes T and Span PN: Correlation of reversioninducing cysteine-rich protein with kazal motifs (RECK) and extracellular matrix metalloproteinase inducer (EMMPRIN), with MMP-2, MMP-9, and survival in colorectal cancer. Cancer Lett 237(2): 289-297, 2006.

18 Takeuchi T, Hisanaga M, Nagao M, Ikeda N, Fujii H, Koyama F, Mukogawa T, Matsumoto H, Kondo S, Takahashi C, Noda M and Nakajima Y: The membrane-anchored matrix metalloproteinase (MMP) regulator RECK in combination with MMP-9 serves as an informative prognostic indicator for colorectal cancer. Clin Cancer Res 10(16): 5572-5579, 2004.

19 Maiese K, Chong ZZ, Shang YC and Hou J: Clever cancer strategies with FoxO transcription factors. Cell Cycle 7(24): 3829-3839, 2008.

20 Guo JP, Tian W, Shu S, Xin Y, Shou C and Cheng JQ: IKBKE phosphorylation and inhibition of FOXO3a: a mechanism of IKBKE oncogenic function. PLoS One 8(5): e63636, 2013.

21 Bullock MD, Pickard KM, Nielsen BS, Sayan AE, Jenei V, Mellone M, Mitter R, Primrose JN, Thomas GJ, Packham GK and Mirnezami AH: Pleiotropic actions of miR-21 highlight the critical role of deregulated stromal microRNAs during colorectal cancer progression. Cell Death Dis 4: e684, 2013.

22 Vishwamitra D, Li Y, Wilson D, Manshouri R, Curry CV, Shi B, Tang XM, Sheehan AM, Wistuba II, Shi P and Amin HM: MicroRNA 96 is a post-transcriptional suppressor of anaplastic lymphoma kinase expression. Am J Pathol 180(5): 1772-1780, 2012.
Received January 23, 2018

Revised February 15, 2018 Accepted February 26, 2018 